\title{
KÜLFÖLDI BEVÁNDORLÓK ÉS BEFEKTETŐK SZEGEDEN
}

\author{
(Immigrants and Foreign Investors in Szeged)
}

\section{SZÓNOKYNÉ ANCSIN GABRIELLA}

Az utóbbi években Magyarországon végbement társadalmi-gazdasági átalakulás nehézségei mellett megjelent egy új, a korábbi 40 évben ismeretlen jelenség: a nemzetközi migráció (a határok átjárhatósága és a környezö országokban lejátszódó politikai, háborús folyamatok teremtette vándorlási hullám), melynek fogadására az önkormányzatok, a kormányzati és a regionális politika nem volt felkészülve. A vizsgált időszakot megelőző négy évtizedben Magyarországon az ország elhagyására az akkori nemzetközi normák szerint nem volt lehetőség, hasonlóan "testvéri" együttmüködés szabályozta a hazánk területére bevándorolni kivánók számát is. Magyarországra a bevándorlási készség a környezö országokból a többszöröse volt az engedélyezettnek. A nehéz körülmények között élő magyar etnikumú népességből sokan választották volna új otthonul Magyarországot. Ebben az időszakban az évenként engedélyezett bevándorlás 1984-ig 1500 fö volt, 1984 és 1988 között már 2000 fö fölötti értéket is elért (Tóth 1993). A szükre szabott lehetőségek miatt a határon kívül élő, áttelepülni vágyó magyar kisebbség számára az egyetlen járható út a házasságkötés volt. Így ezekben az években sok álházasságot kötöttek, különösen az Erdély és a Kárpátalja területéröl átjött fiatalok.

A több mint 40 éves zártság, az évtizedekig elhúzódó, lefojtott vándorlás után, az 1980-as évek végén lezajlott politikai-gazdasági események (elsősorban a Szovjetuniótól való függőség lazulása, majd megszünése, másodsorban Ceausescu hatalmának eltörlése és végül a déli háború kirobbanása) Kelet-Közép-Európa századvégi legnagyobb migrációját indították el. A legnehezebb feladat Magyarországra hárult. Az új bevándorlási törvények bevezetése (Tóth 1996) és a megfelelő intézmények létrehozása ellenére, több év elteltével még ma is arról beszélünk, hogy migrációs stratégiát kell kidolgozni, ahogy L. Rédei Mária (1997) megfogalmazta: „A helyzetünk tudatos felismerésének hiánya, valamint az, hogy nem alakítottunk ki migrációs és menekültügyi stratégiát, odavezetett, hogy ma is az 1992-es kérdésekkel szembesülünk."

A menekültek, bevándorlók ellátásában, társadalmi beilleszkedésük elösegítésében a helyi önkormányzatok szerepe felértékelödött. A letelepedettek szociális, egészségügyi, gyermekvédelmi ellátása, támogatása nem elkülönült szférában, hanem a helyi közösség rendszerén belül valósul meg, ami azt is jelenti, hogy e rendszer ellátását müködtető önkormányzatok, közigazgatási vezetök feladata a településekben szétszórtan élö menekültek, bevándorlók támogatása, és ügyeinek megfelelö intézése. E problémát felismerve a migrációval foglalkozó kutatók a Menedék Egyesület 1997. május 30-án megrendezett konferenciáján felhívta az önkormányzatok figyelmét e téma fontosságára és megfogalmazta a helyi közigazgatás feladatait. 
A tanulmány célja az 1988-1995 között Szegeden lejátszódott migrációs folyamat bemutatása a KSH Népességtudományi Kutató Intézet adatai alapján a bevándorló népesség számának alakulását, szerkezetét és a városban megjelenổ külföldi érdekeltségủ vállalkozásokat, mint a bevándorlással együtt járó jelenséget elemzi. Azért tartom fontosnak a téma kutatását, mert feltételezésem szerint Szeged a vidéki városok közull az ország egyik legjelentôsebb migrácós célállomása.

Továbbiakban a bevándorlók adatai azokra a tartózkodási engedéllyel rendelkezô külfoldi állampolgárokra vonatkoznak, akik legalább egy évet Magyarországon töltöttek és egy évnél hosszabb idöre szóló tartózkodási engedélyt kaptak és 1995 áprilisában még az országban tartózkodtak.

\section{Külföldiek Szegeden}

Szeged a dél-alföldi régió legnagyobb gazdasági- és közlekedési csomópontja, kulturális, szellemi centruma, a "balkán kapuja". A város határ menti földrajzi fekvése és nagysága (területe és népessége) miatt ideális térség a külföldröl jövö letelepedni kivánók számára. A bevándorló népesség megjelenése Szegeden új gazdasági és társadalmi folyamatokat eredményezett, melyek hatása összefonódott a rendszerváltás és az átalakulás folyamataival.

A vándorlás jelentőségét, mértékét az 1000 lakosra számított arányszámmal jellemezhetjük ( $l$. ábra). Ez az érték Szegeden minden évben felülmúlja az országos átlagot, söt 1989-ben, de különösen 1993-ban tőbbszörösen meghaladja azt. A városban lejátszódott migráció jelentőségének nagyságát csak a magyarországi vándorlási folyamatokkal együtt vizsgálva mutathatjuk be.

\section{TÁBLÁZAT}

Magyarországon tartózkodó külföldiek megoszlása (Foreign citizens in Hungary by sending countries)

\begin{tabular}{|l|c|c|c|c|c|c|c|c|}
\hline \multirow{2}{*}{} & \multicolumn{4}{|c|}{$1980-1988$} & \multicolumn{4}{c|}{$1988-1994$} \\
\cline { 2 - 9 } & \multicolumn{2}{|c|}{ száma } & \multicolumn{2}{c|}{ aránya } & \multicolumn{2}{c|}{ száma } & \multicolumn{2}{c|}{ aránya } \\
\hline ország & $\mathrm{A}$ & $\mathrm{B}$ & $\mathrm{A}$ & $\mathrm{B}$ & $\mathrm{A}$ & $\mathrm{B}$ & $\mathrm{A}$ & $\mathrm{B}$ \\
\hline Románia & 6094 & 3429 & 13,4 & 13,4 & 98744 & 65006 & 65,1 & 47,1 \\
\hline Jugoszlávia & 1059 & 908 & 2,3 & 3,6 & 15467 & 14865 & 10,2 & 10,8 \\
\hline egyéb o. & 38203 & 22242 & 84,3 & 87,0 & 37430 & 58230 & 24,7 & 42,2 \\
\hline összesen & 45356 & 25579 & 100,0 & 100,0 & 151641 & 138101 & 100,0 & 100,0 \\
\hline
\end{tabular}

Forrás: KSH Népességtudományi Intézet

$A=$ belépő́k (Az adatok azokra a kulfoldi állampolgárokra vonatkoznak, akik tartózkodási engedéllyel legalább egy évet Magyarországon tôltơttek, vagy egy évnél hosszabb idöre szóló tartózkodási engedélyt kaptak függetlenul attól, hogy jelenleg az országban tartózkodnak-e.)

B=tartózkodási engedéllyel rendelkezök (Az adatok azokra a külfoldi allampolgárokra vonatkoznak, akik tartózkodási engedéllyel legalább egy évet Magyarországon tơltoottek, vagy egy évnél hosszabb idōre szóló tartózkodási engedélyt kaptak és 1995 áprilisában még az országban tartózkodtak.)

Az 1988-tól napjainkig bekövetkezett bevándorlási, menekülési hullám komoly kihívást jelentett hazánk számára. Ezalatt mintegy 200 ezer fôvel nổt az ország lakossága. A migránsok 65\%-a Romániából érkezett hazánk területére, közülük sokan továbbutaztak $(34,2 \%)$, más országban kerestek új otthont maguknak. Jugoszláviából lényegesen kevesebben jőttek Magyarországra, viszont 95\%-uk még ma is az országban tartózkodik. 
1. ÁBRA A Magyarországon és Szegeden tartózkodó külfóldiek aránya

(Proportion of foreign citizens in Hungary and city of Szeged)

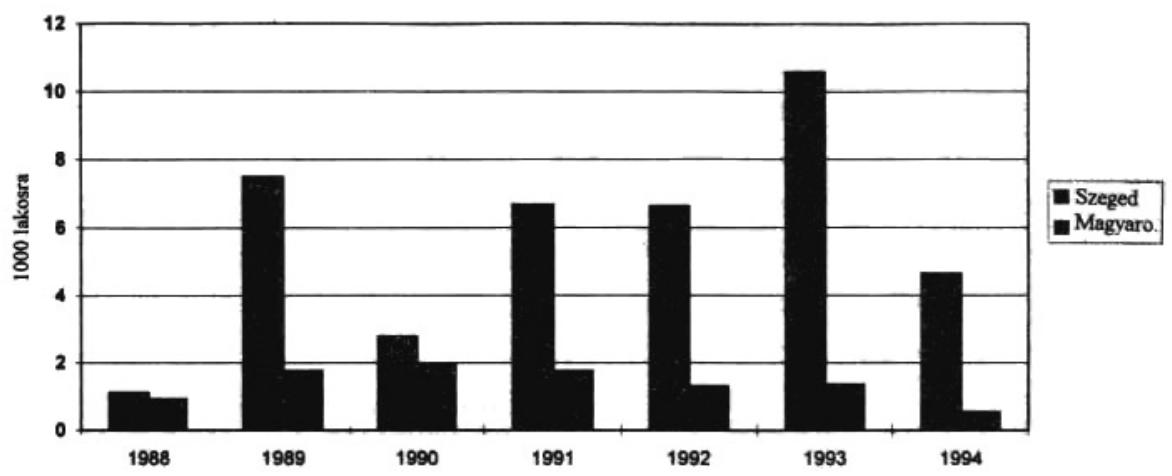

Szegeden tartózkodó külföldiek országos aránya a belépés éve szerint (\%) (National proportion of foreigners staying in Szeged by the year of entering)

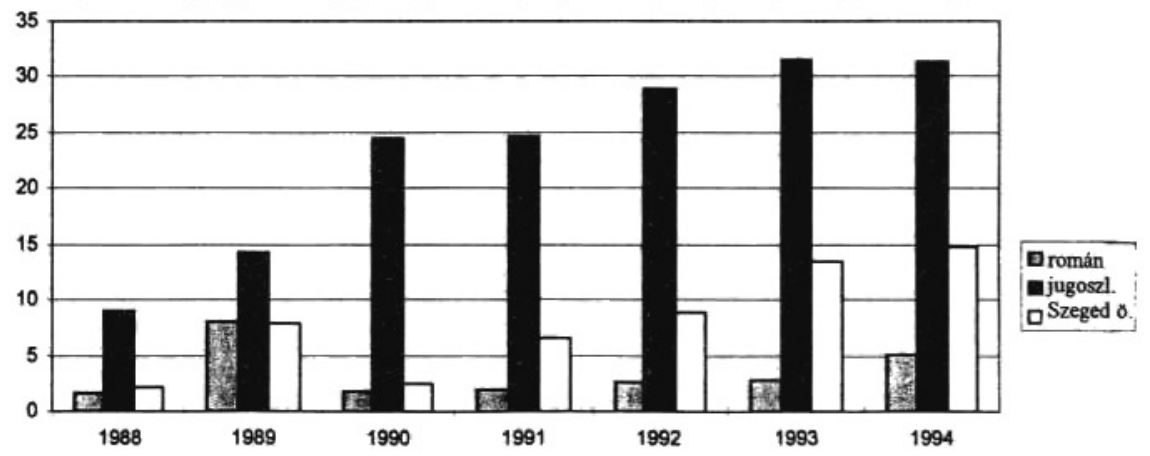




\section{TÁBLÁZAT}

Szegeden tartózkodó külföldiek megoszlása (Foreign citizens in Szeged by sending countries)

\begin{tabular}{|l|c|c|c|c|c|c|c|c|}
\hline \multirow{2}{*}{} & \multicolumn{4}{|c|}{$1980-1988$} & \multicolumn{3}{c|}{$1988-1994$} \\
\cline { 2 - 9 } & \multicolumn{2}{|c|}{ száma } & \multicolumn{2}{c|}{ aránya } & \multicolumn{2}{c|}{ száma } & \multicolumn{2}{c|}{ aránya } \\
\hline Ország & $\mathrm{A}$ & $\mathrm{B}$ & $\mathrm{A}$ & $\mathrm{B}$ & $\mathrm{A}$ & $\mathrm{B}$ & $\mathrm{A}$ & $\mathrm{B}$ \\
\hline Románia & 86 & 31 & 4,8 & 5,1 & 3618 & 2246 & 37.3 & 28,0 \\
\hline Jugoszlávia & 103 & 90 & 5,7 & 14,7 & 4350 & 4195 & 45.0 & 52,2 \\
\hline Egyéb o. & 1604 & 490 & 89,5 & 80,2 & 1719 & 1591 & 17.7 & 20,2 \\
\hline Összesen & 1793 & 611 & 100,0 & 100,0 & 9687 & 8032 & 100,0 & 100,0 \\
\hline
\end{tabular}

Forrás: KSH Népességtudományi Intézet

$\mathrm{A}=$ =belépök (lásd elôbb)

$\mathrm{B}=$ tartózkodási engedéllyel rendelkezök (lásd elöbb)

Szegedre 1988-1995 között közel 10 ezer külföldi érkezett, közülük 8032 fö még ma is a városban tartózkodik. A Szegeden élö külföldiek közül a legtöbben két országból, Romániából és a volt Jugoszlávia területéröl jöttek (az összes bevándorló $82 \%$-a). A városba érkező jugoszlávok, vajdasági magyarok $97 \%$-a még ma is itt él. A Romániából, elsősorban Erdélyböl jövők $62 \%$-a maradt csak a városban. A volt jugoszláv területekröl a városba érkezök aránya az országos adatokból kiemelkedően magas 1990, 1991-ben érkezők 25\%-a, majd az 1992-ben, 1993-ban és 1994-ben a Magyarországra jövők 30\%-a maradt Szegeden (l. ábra). A Romániából hazánkba érkezök közül sokkal kevesebben, csak néhány százalék jött Szegedre, az 1989-es maximum idején sem érte el a $10 \%$-ot.

Az elmúlt 7 év migrációjára jellemző, hogy két nagy hullámban érkeztek külföldiek hazánkba és Szegedre is. Megvizsgálva az éves adatokat, 1989-es és 1993-as maximum mutatható ki. (2. ábra). Az 1989-es keletröl jövők (Romániából érkező, többnyire magyar nemzetiségü) hullámát 1993-ban felváltja a délröl érkező jugoszlávok (többségében vajdasági magyarok) nagy csoportja. Hazánkban a hét év során mindvégig a román betelepülök voltak többségben, a délröl jövők csupán erösítették a második hullámot.

Szegeden élesen elkülönült e két betelepülési hullám, mind nagyságában, mind irányában. 1989-ben a Szegedre érkezök 83\%-a, közel 2000 ember jött keletröl. Ez a hullám 1990-re lecsendesedett és megnött a délröl jövök aránya. Három éven keresztül évente 1000 fönél több jugoszláv állampolgár érkezett Szegedre. Mára a környezö országok stabilizációja elkezdödött, ami azt is jelenti, hogy a jövöben nem várható tömeges bevándorlás hazánk területére és Szeged városába sem. A volt jugoszláv területekre történő visszavándorlás is lassan és fokozatosan következett be. A jövő nagy feladata a bevándorlási törvény tökéletesitése és a letelepedni kívánók társadalmi beilleszkedési lehetöségeinek a megteremtése. Ezért is tartom fontosnak e téma kutatását, különösen települési szinten, hiszen ezen feladatok megoldása elsősorban a helyi vezetőkre vár. 


\section{2. ÁBRA A Magyarországon tartózkodó külfóldi állampolgárok száma a belépés éve szerint \\ (Foreign citizens in Hungary by the year of entering )}

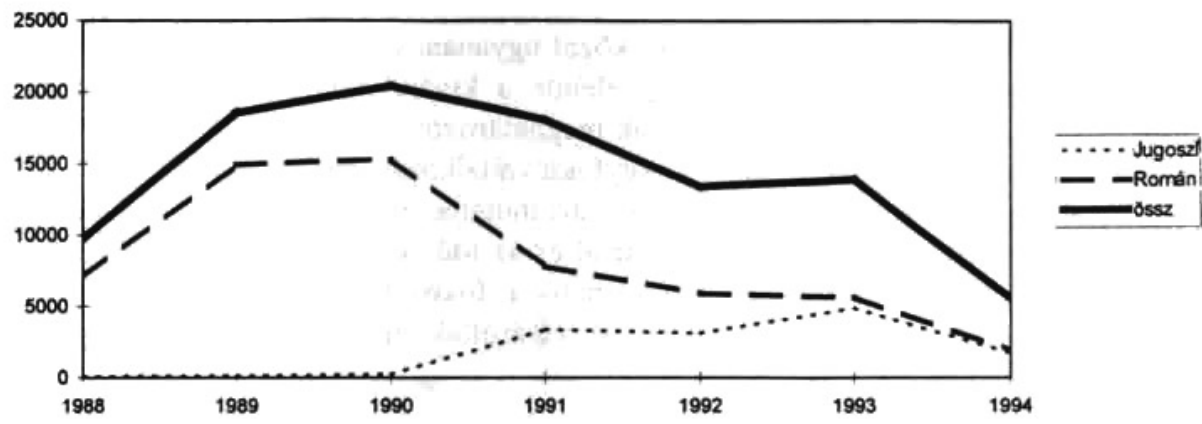

Szegeden tartozkodó külfoldiek száma a belépés éve szerint

(Foreign citizens in Szeged by year of entering)

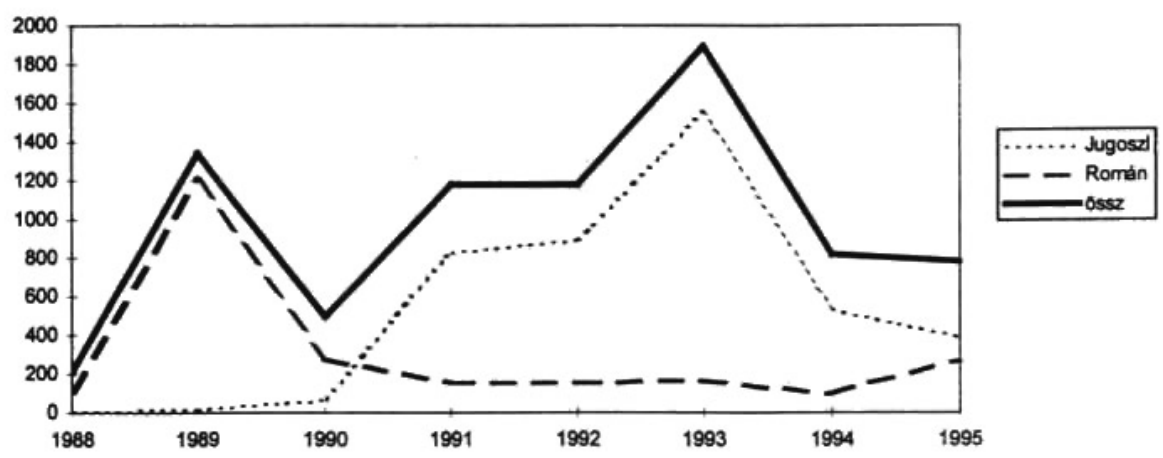




\section{Jugoszlávok Szegeden}

1989-ig Jugoszláviából Szegedre jövök száma (akik egy évnél hosszabb ideig maradtak a városban) még a 100 föt sem érte el (2. táblázat). A politikai krízis, majd az elhúzódó háború elöl menekülök nagy számban érkeztek a városba. Az első két évben az áttelepülök többsége fiatal férfi, akik a katonaság elöl szöktek Szegedre (3.,4. ábra).

1993-tól már nemcsak férfiak, hanem közel ugyanannyi nö is érkezett a városba (elsösorban vajdasági magyarok). Míg eleinte a kivándorlás motívuma politikai eredetủ volt, később a gazdaságok váltak meghatározóvá. A gazdasági menekültek esetében jellemző a tőke átmentése, a nagyfokú vállalkozási hajlandóság.

A városba érkezö népesség korszerkezete azt mutatja, hogy 1993-tól már családok érkeznek Szegedre, ugyanis megnött a fiatal és az idős korúak aránya. A Szegedre jött fiatal, mobil népesség esetében várható a fokozatos visszatelepülés, de a családok esetében, különösen, akik lakást vásároltak már Szegeden, a végleges letelepülés várható.

\section{Romániai magyarok Szegeden}

A Romániából áttelepültek, föként magyar nemzetiségüek kivándorlásának motívuma kezdetben szintén politikai, késöbb inkább gazdasági jellegü volt. Az áttelepülö népesség társadalmi szerkezetére jellemző, hogy két csoport különithetö el. Nagy létszámú csoportot alkotnak a betelepült értelmiségiek, foglalkozásukat tekintve tanárok, orvosok, mérnökök. Az 1989-ben és ezután bevándorlók többsége viszont alacsony iskolai végzettséggel rendelkezö, föleg fizikai munkát vállalók csoportjából kerül ki. Közöttük magas az illegálisan foglalkoztatottak aránya. 1989-ben többségében a férfiak túlsúlya és a fiatal, aktív korosztály nagyobb létszáma jellemzö. Később a férfi-nő arány megegyezik és a fiatal- és időskorúak aránya növekedett az áttelepültek körében.

\section{Külföldi vállalkozások Szegeden}

A vizsgálat alapját a Complex CD Céghírek 1996. március 31-i adatokat tartalmazó kompakt lemezröl kigyüjtött adatok képezték. Ez tartalmazza a Magyarországon bejegyzett összes müködő vállalkozást és azok föbb paramétereit. A külföldi tőkével alapitott vállalkozások 2,6\%-át Szegeden jegyezték be. Ezek között kiugróan magas a jugoszláviai magyarok vállalkozásainak aránya: a hazánkban müködő jugoszláv érdekeltségü vállalkozások 34,3\%-a itt müködik (3. táblázat).

Hasonló határközeli vállalkozásnak tekinthető Pécs városában a horvát befektetések nagy száma és Nyiregyházán az ukrán vállalkozások megjelenése. 
3. ÁBRA A Szegeden tartózkodó jugoszlávok a belépés éve és nem szerint (Yugoslavian citizens in Szeged by gender and year of entering)

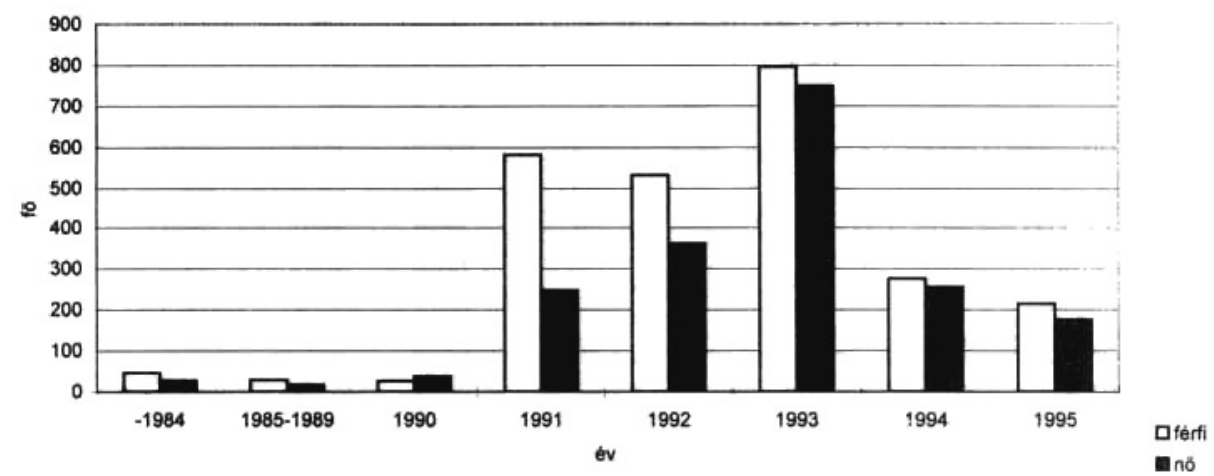

A Szegeden tartózkodó román állampolgárok a belépés éve és nem szerint

(Rumanian citizens by gender and year of entering)

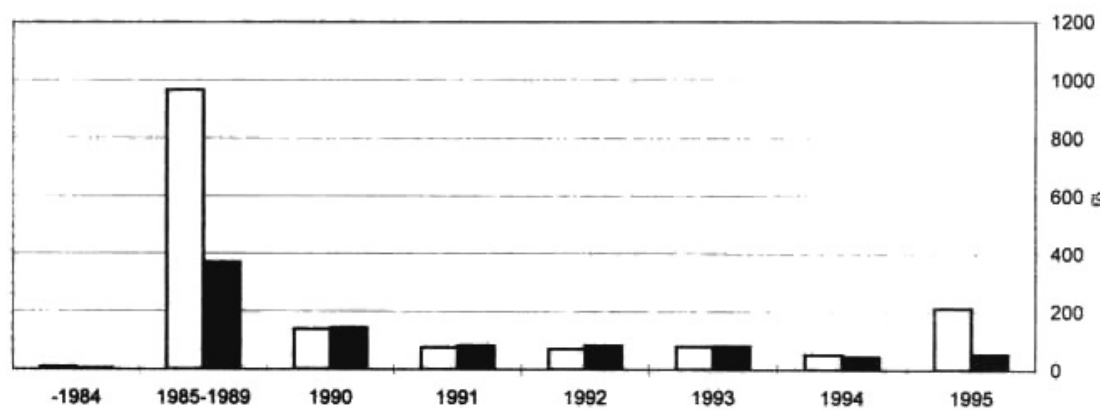

ev 
4. ÁBRA Szegeden tartozkodó jugoszláv állampolgárok a belépés éve szerint korcsoportonként

(Yugoslavian citizens in Szeged by age and year of entering )

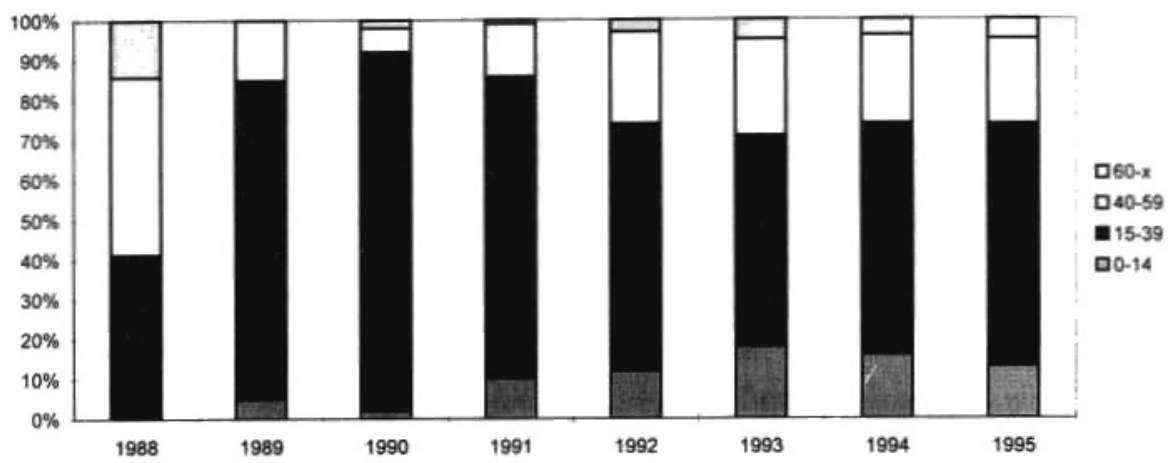

Szegeden tartozkodó román állampolgárok a belépés éve szerint korcsoportonként (Rumanian citizens in Szeged

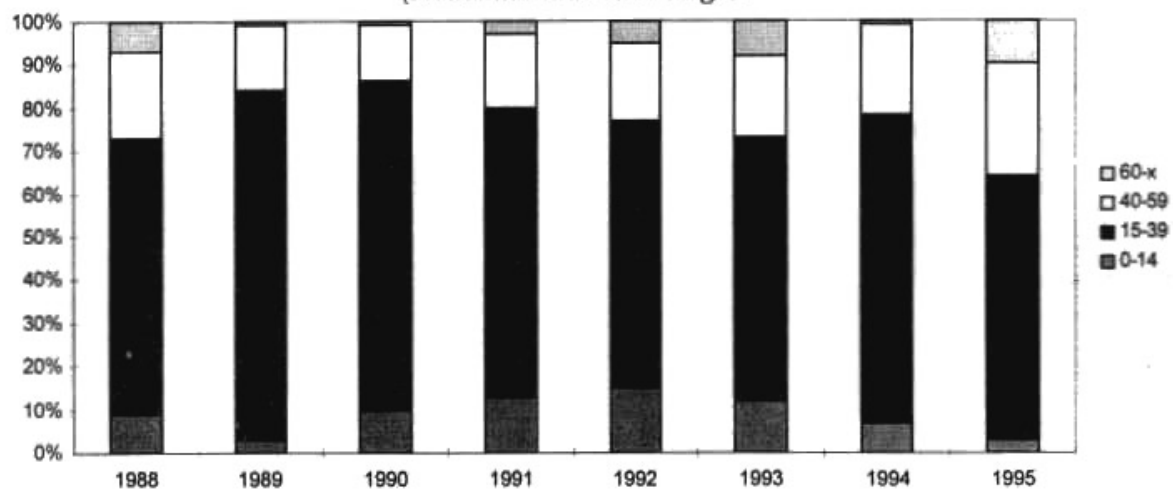




\section{TÁBLÁZAT}

A külföldi érdekeltségü vállalkozások Szegeden (1996, \%-ban)

(Enterprises with foreign capital in several Hungarian cities by capital-exporting countries, \%)

\begin{tabular}{|l|c|c|c|c|c|}
\hline \multicolumn{1}{|c|}{ Települések } & Jugoszláv & Román & Ukrán & Horvát & Kínai \\
\hline Szeged & 33,5 & 3,6 & 3,3 & 4,1 & 0,5 \\
\hline Pécs & 1,5 & 1,0 & 1,4 & 23,8 & 0,4 \\
\hline Debrecen & 0,1 & 1,6 & 2,3 & - & 0,4 \\
\hline Nyíregyháza & 0,1 & 1,1 & 8,5 & - & 0,6 \\
\hline Budapest & 10,9 & 25,5 & 28,6 & 13,2 & 81,7 \\
\hline Magyarország & 100,0 & 100,0 & 100,0 & 100,0 & 100,0 \\
\hline
\end{tabular}

\section{Jugoszláv vállalkozások}

A jugoszláv cégalapítások kiugróan magas száma Szegeden 1992-ben és 1993-ban a háború erösödésével magyarázható, majd 1994-töl fokozatosan csökkenö tendenciájú (5. ábra). Az 1980-as évek közepén már valuta formájában elkezdödött a tőkeátmentés, ugyanis sok jugoszláv vállalkozó a Szegedi OTP-ben helyezte el tőkéje nagy részét és ott biztonságban érezve tárolta. Ahogy lehetőség nyilt rá az 1990-es évek elején, tőkéjét felhasználva vállalkozásba kezdett Szegeden, föként a kereskedelmi szférában. A városban létrejött jugoszláv vállalkozásokra 1992-ig a magasabb alaptőkéjủ jellemző, melyek sikerét garantálta a vállalkozók nagy szakértelme is, amit korábban az otthoni vállalkozások révén megszereztek.

A folyamat eredményeként jelentös üzletláncok létesültek Szegeden, melyeket a többlábon állás és a siker jellemez ma is. Az 1992-ben és 1993-ban megalakult új, jugoszláv érdekeltségü cégek $85 \%$-a a betéti társasági formát választotta (6. ábra). Ebben az időben a háború elöli menekülök (föként fiatalok) már nem rendelkeztek komoly befektethető tőkével. Így a kis alaptőkéjủ vállalkozások tömegét alapították, melyek alapmotívuma sok esetben a munkavállalási engedély megkerülése volt.

\section{Egyéb külföldi befektetések}

A román vállalkozások száma csekély a városban, összesen 25 . A Romániából áttelepültekre jellemzö, hogy kevés tőkével rendelkeztek és inkább munkavállalás céljából jöttek.

Még ennél is kevesebb az ukrán vállalkozások száma. A jugoszlávéhoz hasonlóan a román vállalkozások esetében is magas a betéti társaság-alapítások aránya (76\%). $\mathrm{Az}$ ukránok és a volt Szovjetunió területéröl érkezök, a várost inkább üzleti találkozóhelyként használják, mivel a jugoszláv ill. román üzletemberek számára a három határú város ideális fekvésü, és nagyságánál fogva is rendkivül kedvezö üzleti tárgyalások céljára. A kínai vállalkozók viszont többségében korlátolt felelősségü társaságokat alapítottak Magyarországon és Szegeden is, viszonylag magas (1 millió Ft körüli) alaptökével. 


\section{5. ÁBRA A jugoszláv vállalkozások a cég tevékenysége megkezdésének idôpontja} szerint

(Number of enterprises with Yugoslavian capital by the year of establishment)

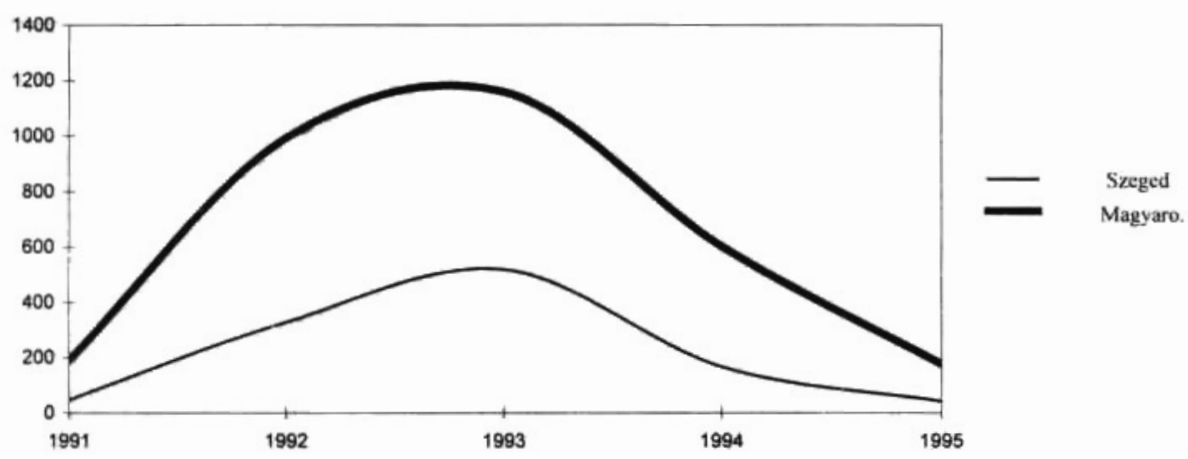

6. ÁBRA A jugoszlóv vállalkozások Szegeden az alaptôke nagysága és a cégalapitás idôpontja szerint

(Yugoslavian enterprises by capital and year of registration)

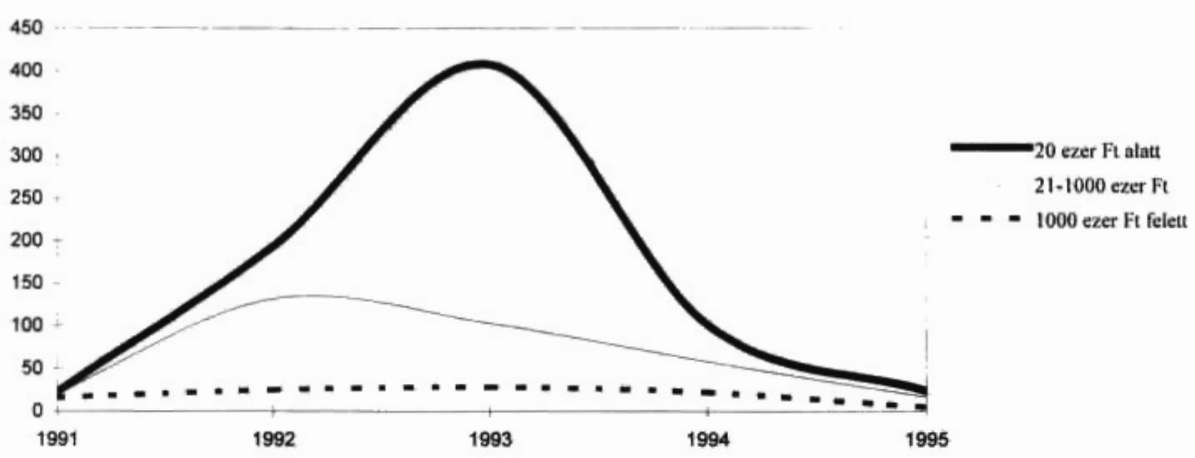




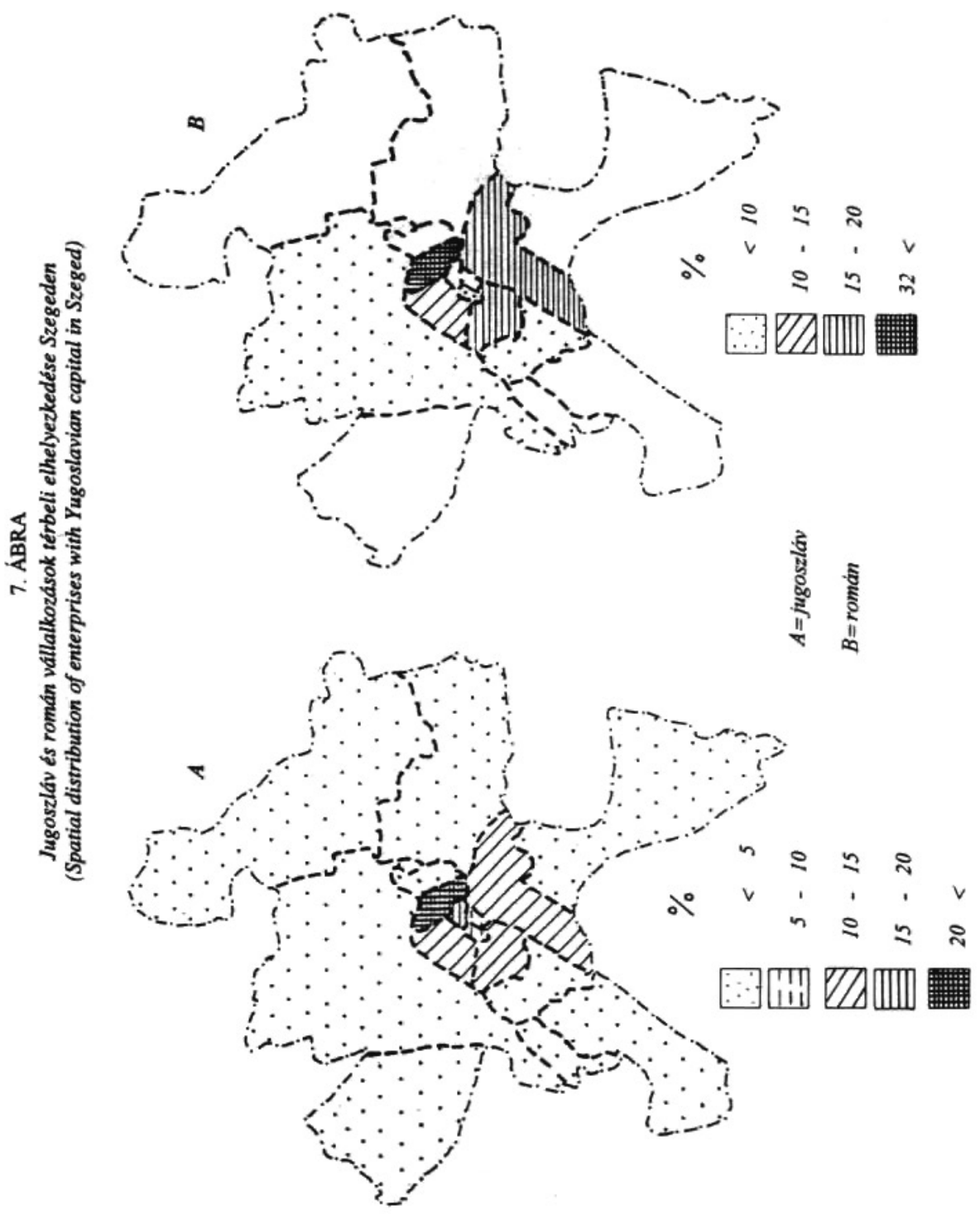




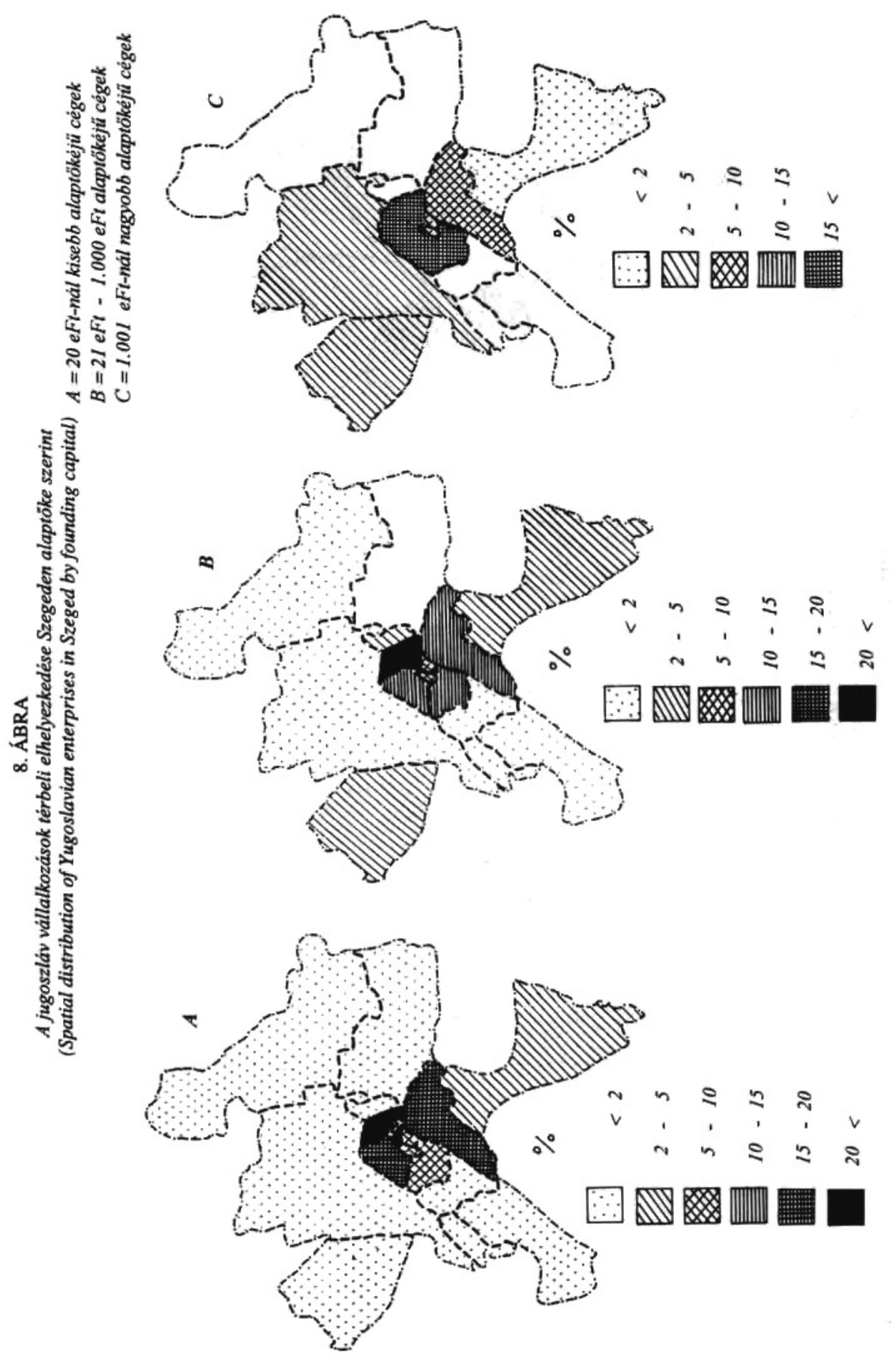




\section{A vállalkozások területi elhelyezkedése}

A jugoszláv vállalkozások Szeged összes városrészében megtalálhatók és a legtöbb telephely a Tarján város és Felsőváros lakónegyedében helyezkedik el (7. ábra). Bár a román cégek sokkal kisebb számban vannak jelen Szegeden, területi elhelyezkedésúk az előbbi csoporthoz hasonlók, annyi különbséggel, hogy ezek a vállalkozások Szeged város külső övezetében nem fordulnak elö. A vállalkozások többsége bérelt lakásokban müködik, ezt igazolja a telephelyek területi elhelyezkedése is a városon belül. A kis alaptőkéjü (20 ezer Ft-nál kisebb alaptökéjü) vállalkozások (8. ábra) a szüken értelmezett belvároson kívül, a lakónegyedekben találhatók és ezek közül is leginkább Tarján telep és Felsöváros olcsó bérü lakásaiban. A magas alaptökéjü cégek (1 millió $\mathrm{Ft}$ feletti) a belvárosban tömörülnek, bár ezek esetében is fontos térség a már említett két lakónegyed.

\section{Irodalom}

Dơvényi Z. (1997) Adalékok a Magyarországon élö "idegenek" területi megoszlásához. 97-105 o. (In: Migráció és politika, Szerk: Sik E., Tóth J.) MTA Politikai Tudományok Intézete, Budapest.

Hárs Á. (1995) Idegen népesség, migráns munkaerő, Európa Fórum V. évf. 1.sz. 45-58. o.

Illés S. (1995) A területi mobilitás volumenének változásai. Statisztikai Szemle 73. 7.sz. 543-555. o.

Juhász J. (1994) A Magyarországot érintő nemzetkozi vándorlás. Demográfia 37. 1. sz. 32- 59. o.

L. Rédei M. (1994) Az 1956-1992 kőzötti nemzetkőzi népességmozgások jellemzöi Magyarországon. Foldrajzi Értesitő XLIII. évf. 1-2. fùzet 57-74 o.

L. Rédei M. (1997) Magyarország nemzetkőzi migrációs vonásai a 90-es években (kézirat)

Pál Ágnes - Szónokyné Ancsin Gabriella (1994) Határon innen - határon túl. Határ menti települések osszzehasonlitó gazdasági elemzése a Dèl-Alfoldoon. Alfoldi Társadalom. Békéscsaba. 241-245.o.

Sik E.(szerk.) (1992) Menekülök, vándorlók, szerencsét próbálók. MTA. Politikai Tudományok Intézete, Budapest.

Sik E.(szerk.) (1992) Útkeresők. MTA. Politikai Tudományok Intézete, Budapest.

Szónokyné Ancsin G. (1996) A jugoszláv betelepalök társadalmi-gazdasági struktúrája Szegeden. (In: Migráció és politika Szerk: Sik E., Tóth J.) MTA Politikai Tudományok Intézete, Budapest.

Tóth Pál P. (1993) A nemzetkőzi vándorlás, Magyarország, KSH Népességtudományi Kutató Intézet, Budapest.

Tóth Pál P. (1996) A Magyarországra menekulök, 1988-1994. Statisztikai Szemle 74. 5-6. sz. 438-459. o.

Tóth Pál P. (1997) Menedékesek Magyarországon 1996 szeptemberében. (In: Migráció és politika Szerk: Sik E., Tóth J.) MTA Politikai Tudományok Intézete. Budapest. 